\title{
Effect of enzymatic treatment of flax on fineness of fibers and mechanical performance of composites
}

Jana De Prez ${ }^{1 *}$, Aart Willem Van Vuure ${ }^{2}$, Jan Ivens ${ }^{3}$, Guido Aerts ${ }^{1} \&$ Ilse Van de Voorde ${ }^{1}$

${ }^{1} \mathrm{KU}$ Leuven, Faculty of Engineering Technology, Department of Microbial and Molecular Systems $\left(\mathrm{M}^{2} \mathrm{~S}\right)$, Cluster for Bioengineering Technology ( $\mathrm{CBeT})$, Laboratory of Enzyme, Fermentation and Brewing Technology (EFBT), Technology Campus Ghent, Gebroeders De Smetstraat 1, B-9000 Ghent, Belgium

${ }^{2} \mathrm{KU}$ Leuven, Faculty of Engineering Technology, Department of Materials Engineering (MTM), Technology Cluster for Materials Technology (TC-MT), Campus Group T, Andreas Vesaliusstraat 13, B-3000 Leuven, Belgium

${ }^{3} \mathrm{KU}$ Leuven, Faculty of Engineering Technology, Department of Materials Engineering (MTM), Technology Cluster for Materials Technology (TC-MT), Campus De Nayer, De Nayerlaan 5, B-2860 Sint-Katelijne Waver, Belgium

jana_deprez@hotmail.com * corresponding author

aartwillem.vanvuure@kuleuven.be

jan.ivens@kuleuven.be

guido.aerts@kuleuven.be

ilse.vandevoorde@kuleuven.be

Abstract

The application of enzymes as alternative to dew retting of flax was studied in correlation to the characteristics of composites reinforced with these natural fibers. Fiber fineness and mechanical properties of biocomposites were evaluated. Furthermore, moisture absorption by biocomposites was studied and fracture surfaces were investigated using Scanning Electron Microscopy. Compared to dew retted fiber composites, improvements in mechanical performance can be observed for composites impregnated with fibers extracted after enzymatic treatments. All enzymatic treatments resulted in finer fibers than green fibers and led to biocomposites with a reduced equilibrium moisture content and lower diffusion coefficient. This study illustrates the high potential of enzymatic retting, in particular with polygalacturonase. Also, the manual extraction procedure used, produced fibers with an E-modulus up to $84 \mathrm{GPa}$ and strength up to $800 \mathrm{MPa}$, likely due to reduced fiber damage, which illustrates the hidden potential of flax fibers. 
Keywords: A: natural fibers, A: biocomposite, B: mechanical properties, enzymatic treatment

\section{Introduction}

The utilization of natural fibers in composites (natural fiber reinforced composites, NFRC) has gained much popularity as an alternative for glass fiber reinforced composites (GFRC), thanks to their high specific mechanical properties. Flax (Linum usitatissimum), hemp and ramie are the most promising natural fibers to replace glass fibers due to their high specific Young's modulus and tensile strength [1]. Moreover, natural fibers are a renewable resource and environmentally friendly. Hence, introducing NFRC as an alternative for GFRC would be a great step forward towards a more sustainable bio-based economy. A promising future exists for NFRC's with applications in automotive, mobility and transport, sports and leisure, wind energy, aerospace, etc. [2]. Hence the production of NFRC must be fully explored and optimized to guarantee its future potential.

Replacing the traditional dew retting process by enzymatic retting can make a substantial contribution towards the substitution of GFRC by NFRC. Dew retting is an important step in the processing of flax for composite applications. During dew retting, flax fibers are loosened from the stem by interaction of microorganisms. The impact of dew retting on flax fiber composition as well as on fiber fineness and mechanical performance of composites has been addressed by some research groups [3-7]. Akin et al. [3] observed a purification of the fiber with increased cellulose content $(65 \mathrm{w} / \mathrm{w} \%)$ after dew retting compared to unretted flax fibers $(43 \mathrm{w} / \mathrm{w} \%)$. A refining was established after dew retting, while promising composite properties were observed $[4,6]$. The transverse bending strength of a unidirectional epoxy composite based on dew retted fibers was increased with $40 \%$ compared to the green fiber-epoxy composite [6]. Martin et al. [7] observed increased tensile properties of single fibers with increased retting degree, as well as increased mechanical properties for polypropylene composites reinforced with short fibers. However, a decrease of $15 \%$ in fiber strength has been observed when flax was harvested 5 days after the optimal harvest time $[1,8]$. This implies that flax farmers need to correctly evaluate the retting process based on experience and decide which is the rightful time for harvesting. The process of dew retting is 
thus very dependent on weather conditions, but also region and climate changes. Along with the long duration of the process, these factors give rise to an inconsistent fiber quality.

Enzymatic retting should enable us to produce flax fibers with a more consistent and higher quality but also should result in a higher fiber yield. A comprehensive summary of research results available on enzymatic treatment of natural flax stems or fibers has been reported by De Prez et al. [9]. Enzymes tested in this study were investigated in previous research [10] concerning the effect of enzymatic treatments on the chemical composition of the extracted fibers and the influence on ease of fiber extraction. Chemical characterization of the fiber, i.e. determination of the cellulose, hemicellulose, lignin and pectin content is necessary to understand the purifying effect of the enzymes. A higher extraction efficiency (EE) implies a less severe subsequent mechanical extraction is needed and thus less fiber damage will occur. Pectate lyase, polygalacturonase and xylanase showed most potential when chemical composition as well as EE were taken into account. However, next to these criteria, it is important to characterize mechanical properties of composites, reinforced with the extracted flax fibers after enzymatic treatment as the extracted flax fibers are intended for use in composite applications.

Only a few research groups investigated the mechanical performance of composites reinforced with fibers after enzymatic treatment. George et al. [11] reported the tensile properties of polypropylene composites reinforced with pelletized flax fibers (using a Kahl pellet press). Enzymatic treatments were performed directly on flax fibers in the research of George et al. [11]. Stuart et al. [12] described tensile properties of reinforcement 'mats' with epoxy and enzymatically treated flax fibers and showed promising results for enzymatic treatment in the presence of ethylenediaminetetraacetic acid (EDTA).

Also fiber fineness is an important factor to take into account when evaluating enzymatic treatments. Enzymatic action involves degradation of the surrounding network of the fiber by affecting hemicellulose and pectin. Through this, fibers are loosened from the bast stem and separated from each other. A correlation can thus be found between fineness of extracted fibers and the effectiveness of the enzymatic action. In previous research, fineness is often determined by characterization of air permeability with the airflow method and expressed as micronaire value [13-17]. 
Moreover, moisture sensitivity remains a drawback for natural fibers and natural fiber reinforced composites and has been extensively studied [11,18-27]. Assarar et al. [28] observed a higher water uptake for flax fiber composites in comparison with glass fiber composites. In humid conditions, fibers will modify structurally due to moisture absorption and this will have an effect on the mechanical properties of the fibers and the composites [21].

In this study, enzymatic treatments are performed directly on flax stems in order to find an alternative process for dew retting. The performance of the unidirectional flax fiber-epoxy composites was investigated by characterizing longitudinal tensile and transverse three-point bending properties. Furthermore, fineness of extracted fibers is characterized by determination of the fiber width in $\mu \mathrm{m}$. Since enzymes attack hydrophilic polymers (pectin and hemicellulose) around the fiber, overall moisture sensitivity can decrease. Hence, the effect of enzymatic treatments on moisture absorption characteristics of composites is also analyzed in this study by determination of equilibrium moisture content (EMC) and diffusion coefficient. Morphological analysis of fracture surface with Scanning Electron Microscopy (SEM) was performed to investigate where failure occurred.

\section{Materials and methods}

\subsection{Materials}

Green flax (GR) from the Amina cultivar was harvested by Verhalle in Belgium in 2015 (VHGR15B). This green flax was used as starting material for all enzymatic treatments. Fibers from green flax were manually extracted, i.e. the fibers are gently pulled down from the woody core from top to bottom. These green fibers were used as reference fibers. Dew retted flax material of the same cultivar was provided by Verhalle, which means the green flax (VHGR15B) remained on the field to let the dew retting process occur (VHDR15B). Fibers were manually extracted from the dew retted flax stems, resulting in manually extracted dew retted fibers (DRm). To compare manual extraction with the traditional extraction method, scutched dew retted fibers and FlaxTape were taken into account as well. The scutched dew retted fibers (DRs), provided by Vanacker Rumbeke, were obtained from harvested flax from France (2017) and were hence from a different cultivar as GR and DRm. Finally, FlaxTape (FT) (with a density of $200 \mathrm{~g} / \mathrm{m}^{2}$ ) from 
Lineo was included as a reference material and is a commercially available hackled flax fiber product of an unknown cultivar. For further comparison, two additional reference treatments are included as well, i.e. water treatment and EDTA treatment. All references and their specifications are illustrated in Table 1.

Table 1. References and specifications concerning origin and extraction method

Enzymes Scourzyme L (Sc, CAS 9015-75-2), NS59049 (NS, CAS 9033-35-6) and Pulpzyme (Pz, CAS 9025-574) were provided by Novozymes (Switzerland). Polygalacturonase from Aspergillus niger (PAn, CAS 903275-1) and xylanase from Thermomyces lanuginosus (XTI, CAS 37278-89-0) were purchased from SigmaAldrich. Rohapect MPE (MPE, CAS 9025-98-3) was obtained from AB Enzymes (Germany). All enzymes were characterized and enzyme activities were discussed and published in De Prez et al. [10].

\subsection{Enzymatic treatment}

Four pectinases, i.e. Scourzyme L (Sc, a pectate lyase), NS59049 (NS, a pectin lyase), Rohapect MPE (MPE, a pectinmethylesterase) and a polygalacturonase from Aspergillus niger (PAn), and two hemicellulases, Pulpzyme (Pz, endoxylanase) and a xylanase from Thermomyces lanuginosus (XTI) were tested. Enzymatic treatments were performed on green flax according to the protocol described in De Prez et al. [6]. Green flax stems (50 g) were incubated at $40{ }^{\circ} \mathrm{C}$ during $24 \mathrm{~h}$ in a $1 \mathrm{~L}$ enzyme formulation containing $0.30 \mathrm{v} / \mathrm{v} \%$ enzyme (with exception of $0.60 \mathrm{v} / \mathrm{v} \%$ for PAn) and $25 \mathrm{mM}$ EDTA at $\mathrm{pH}$ 6.5. After treatment, washing and drying, fibers were manually extracted as described in De Prez et al. [6]. Enzymatic treatments were effectuated twice and resulting fibers from each batch were used for impregnation in composite materials to evaluate mechanical properties. Water treatment (treatment with tap water at $40^{\circ} \mathrm{C}$ during 24 hours) and EDTA treatment ( $25 \mathrm{mM}, 40{ }^{\circ} \mathrm{C}$ during 24 hours) were performed on green flax as reference treatments. An overview of all treatments is illustrated in Table 2. After these treatments, fibers were manually extracted. Reference materials for evaluating performance characteristics are GR (i.e. green fibers manually extracted from the plant stems without any retting or other treatment), fibers extracted after water treatment and after EDTA treatment, dew retted fibers (DRm and DRs) and FlaxTape (FT), as illustrated in Table 1. Manually extracted dew retted fibers (DRm) as well as mechanically scutched dew 
retted fibers (DRs) were included as references in order to determine the influence of the mechanical post-treatment.

Table 2. Overview of different treatments of flax (fibers were all manually extracted)

\subsection{Fineness measurement}

To determine the fineness of manually extracted fibers after enzymatic treatment, an automated image analysis method was used [29]. Fiber width was measured by scanning the fibers with a resolution of 2400 dpi as described in $[6,29]$. The output of the method is a distribution curve of the diameters of the fibers.

\subsection{Composite production}

Unidirectional composites were produced using the Impregnated Fiber Bundle Test methodology (IFBT), based on ISO 10618 . Conditioned $\left(24 \mathrm{~h}\right.$ at $60^{\circ} \mathrm{C}$ ) pre-dried fiber bundles of $20 \mathrm{~cm}$ length were weighed accurately to produce composites with a fiber volume fraction of $40 \%$. To produce composite samples with a $2 \mathrm{~mm}$ thickness, a width of $10 \mathrm{~mm}$ and a length of $200 \mathrm{~mm}, 2.3 \mathrm{~g}$ fibers (with a fiber density of 1.45 $\mathrm{g} / \mathrm{cm}^{3}$ ) were needed to achieve a fiber volume fraction of $40 \%$.

For composite production, epoxy resin was utilized as matrix. The epoxy resin Bisphenol A diglycidyl ether (Epikote 828 LVEL) was blended with the hardener 1,2-diaminocyclohexane (Dytek DCH-99) with a resinto-hardener ratio of 100:15.2. The mixture was then placed in a vacuum at room temperature to remove air bubbles, in order to prevent porosities during composite production.

Fiber bundles were immersed twice in resin and the redundant resin was manually removed from the fiber bundles. An immersed fiber bundle was placed in a vacuum bag in the mould and spacers of $2 \mathrm{~mm}$ were added to guarantee a constant thickness before placing the counter mould. On top of the mould, a Teflon film and a layer of breather was placed in order to equally distribute the pressure on the surface. The mould went into a manual press for 1 hour at $70{ }^{\circ} \mathrm{C}$ and then post-curing took place during 1 hour at $150{ }^{\circ} \mathrm{C}$. After cooling, composite samples were removed from the mould. At least 4 composite samples 
were prepared for each batch of enzymatic treatment. After sanding of the edges, samples were ready for tensile testing.

In order to evaluate transversal properties, composite samples with dimensions of $2 \mathrm{~mm}$ thickness, 25 $\mathrm{mm}$ width and $120 \mathrm{~mm}$ length were produced according to the abovementioned method. These composite samples were then sawn with the diamond saw into six or seven samples with dimensions of $2 \mathrm{~mm} \times 13 \mathrm{~mm} \times 25 \mathrm{~mm}$ and dried $\left(24 \mathrm{~h}\right.$ at $\left.60^{\circ} \mathrm{C}\right)$ prior to three-point bending testing.

\subsection{Tensile testing}

Longitudinal tensile properties of the composites were tested on an Instron 5567 mechanical testing machine with a load cell of $30 \mathrm{kN}$, according to ASTM D3039 [30]. The gauge length was $150 \mathrm{~mm}$ and a 50 $\mathrm{mm}$ extensometer was placed on the middle of the sample to measure strain with a crosshead displacement rate of $2 \mathrm{~mm} / \mathrm{min}$.

Tensile strength and tensile modulus of the composites were calculated. Two moduli were determined for tensile testing: E1, the stiffness between 0.0 and $0.1 \%$ strain and E2, the stiffness between 0.3 and $0.5 \%$ strain, since there can typically be a decrease in stiffness around $0.2 \%$ strain in case of flax fiber composites.

\subsection{Three-point bending testing}

Transverse strength of the composite samples was measured by three-point bending on an Instron 5567 with a load cell of $1 \mathrm{kN}$, according to ASTM D7264 [31]. The crosshead displacement rate was $0.5 \mathrm{~mm} / \mathrm{min}$. The diameter of the loading nose was $6 \mathrm{~mm}$ while the diameter of the support rolls was $4 \mathrm{~mm}$, with a span length of $16 \mathrm{~mm}$.

\subsection{Fracture surface analysis with SEM}

The fracture surface of composite samples subjected to three-point bending tests was analyzed with a SEM (Philips SEM XL3OFEG). A thin gold/palladium film was sputtered on the samples as a conductive 
coating and samples were kept under vacuum until imaging by SEM using a beam voltage of $10 \mathrm{kV}$ with a charge-coupled device (CCD) camera.

\subsection{Moisture absorption of composites}

According to the standard test method (ASTM D5229) [32], the equilibrium moisture content (EMC) and the diffusion coefficient of composite samples were determined. The composite samples were dried at $60{ }^{\circ} \mathrm{C}$ during at least one week before first weight measurement was done. Afterwards, samples were stored in an $80 \%$ relative humidity environment at $80^{\circ} \mathrm{C}$ until constant weight to assure EMC was reached. The results were normalized at a $40 \%$ volume fraction. The diffusion coefficient was calculated assuming Fickian behavior:

$$
\mathrm{D}=\pi\left(\frac{h}{4 M_{m}}\right)^{2}\left(\frac{M_{2}-M_{1}}{\sqrt{t_{2}}-\sqrt{t_{1}}}\right)^{2}
$$

With $D$ the diffusion coefficient $\left(\mathrm{mm}^{2} / \mathrm{s}\right), h$ the average specimen thickness $(\mathrm{mm}), M_{m}$ the effective moisture equilibrium content (\%) and $\left(\frac{M_{2}-M_{1}}{\sqrt{t_{2}}-\sqrt{t_{1}}}\right)$ the slope of the moisture absorption plot in the initial linear portion of the curve $\left(\sqrt{s}^{-1}\right)$ [32].

\subsection{Statistical analysis}

Statistical analysis was performed by running one-way Analysis of variance (ANOVA) in SPSS (IBM, version 25) with a confidence level of $95 \%$ with Tukey correction.

\section{Results and discussion}

\subsection{Fineness of fibers}

The retting effect of enzymatic treatments on flax can be evaluated by fineness measurements. Enzymes react on the surrounding network of the fibers, resulting in separation of fiber bundles of the woody core and further individualization of technical fibers in the bundle. The fineness measurement analysis results in a distribution curve of measured fiber widths, which is illustrated in Figure 1 for GR and FT. 
Figure 1. Fineness distribution curve of (A) GR and (B) FT

The distribution curves in Figure 1 show that GR fibers exhibited a high variety of fiber widths. For FT on the other hand, almost $40 \%$ of the fibers possessed a fiber width of 40 till $60 \mu \mathrm{m}$. Mechanical hackling clearly induced further fibrillization of the technical fibers, resulting in a high percentage of small fiber widths. Finer fibers show an increased surface to mass ratio and possess hence a larger interfacial area between fiber and matrix [33]. Composites with finer fibers exhibit hence a lower fraction of elementary fibers bonded to other elementary fibers through the weak pectin rich middle lamellae, this weak pectin interface usually contributing to risk of failure [34]. Results of the fineness analysis of all fibers extracted after enzymatic treatment is shown in Table 3. This table also includes the fineness of the fibers of the reference materials.

Since a distribution curve is obtained, no standard deviations can be given but median, average and maximum fiber widths are shown, along with the percentage of fibers with a fiber width higher than 300 $\mu \mathrm{m}$ and smaller than $100 \mu \mathrm{m}$.

Table 3. Results of analysis of fiber fineness with average, median and maximum value as well as percentages of fiber widths higher than $300 \mu \mathrm{m}$ and smaller than $100 \mu \mathrm{m}$

Results in Table 3 indicate that GR fibers were the coarsest and that each treatment resulted in a decrease in fiber width compared to GR. DRs showed somewhat finer fibers compared to DRm due to mechanical impact. FT clearly consisted of the finest fibers with the lowest average, median and maximum values. The percentage of fibers $>300 \mu \mathrm{m}$ were highest for GR and clearly decreased after all reference and enzymatic treatments. Enzymatic treatments realized only a small increase in percentage of fibers $<100$ $\mu \mathrm{m}$, indicating that mainly coarse technical fiber bundles were further separated due to the enzymatic treatments. The percentage of fibers with a smaller width than $100 \mu \mathrm{m}$ was highest for FT. A percentage of 68.9 of the fibers showed a fiber width below $100 \mu \mathrm{m}$. FT is a commercially available product of mechanically hackled flax fibers whereby the hackling step further increased fiber fineness and purity. However, the additional mechanical treatment also results in fiber damage, reduced fiber yield and an 
increased cost. All other fibers were subjected to manual extraction and hence no further separation of fibers took place by mechanical interference.

It should be noted that the green fibers of the Amina cultivar (GR) already possessed a very low fiber width. For underretted, dew retted and overretted fibers, gravimetric diameters between the range of 225 to $525 \mu \mathrm{m}$ have been reported [4]. Reference materials like fibers treated with water and EDTA and DRs showed an important improvement in fineness compared to GR. Enzymatic treatments realized an improvement as well but however to a lesser extent.

Akin et al. [35] investigated fiber width after enzymatic treatment with light microscopy and image analysis. Enzymatic treatments were performed in buffer solutions, i.e. a morpholinoethane sulphonic acid (MES) buffer at pH 6.0. With MES buffer alone as a control treatment, $32.0 \%$ of the fibers possessed a fineness within the range of $110-200 \mu \mathrm{m}$, while only $2.7 \%$ lied within the range of $10-30 \mu \mathrm{m}$ [35]. After enzymatic treatment with endopolygalacturonase (EPG) and EPG combinations, fiber widths decreased significantly to approximately $50 \%$ of the fibers in the $10-30 \mu \mathrm{m}$ range [35]. Fineness however was determined on fiber material after Fried Test studies. To perform Fried Tests, enzymatic treatment $(24 \mathrm{~h})$ was followed by decanting, immersion in boiling water, mechanical mixing and shaking to release fibers from stems [35]. Evidently, all the extra handling results in further fibrillation of the fiber till elementary fibers are obtained and hence a lower fiber width is observed. Biagiotti et al. [36] reported fiber widths within a range of 40-620 $\mu \mathrm{m}$ for flax fibers, including technical as well as elementary fibers. Elementary fibers have a fiber diameter between 10 to $40 \mu \mathrm{m}$, depending on growing conditions. Fiber bundles on the other hand consist of several elementary fibers and exhibit a fiber diameter of approximately 100 to $200 \mu \mathrm{m}$, which corresponds to the average fiber widths reported in Table 3. Characterization of fiber widths in this study shows hence a promising fineness after enzymatic treatment.

\subsection{Tensile properties of composites}

To allow a breakthrough of high quality composites impregnated with flax fibers, mechanical performance of the material is of utmost importance. Besides fiber fineness, mechanical performance of the composites was evaluated by characterization of longitudinal tensile properties and transversal bending 
properties. Tensile testing of the composite provides information about the longitudinal Young's modulus of the composite, more specifically the E1- and E2-modulus in different strain ranges. Deviations in dimensions of composite specimens were taken into account to determine the rightful fiber volume fraction. Values were then normalized for each composite according to a $50 \%$ fiber volume fraction to make a rightful comparison. The results for the E1- and E2-moduli of the composites are shown in Figure $2 \mathrm{~A}$.

Composites reinforced with GR fibers possessed an E1-modulus of $39 \pm 1 \mathrm{GPa}$. When comparing the other reference materials with GR, it can be concluded that fibers extracted after water and EDTA treatment resulted in composites with a similar E1-modulus of $40 \pm 1 \mathrm{GPa}$ and $42 \pm 1 \mathrm{GPa}$, respectively ( $\mathrm{P}>0.05)$. Dew retting led to fibers with comparable properties when impregnated in composites in the case of manual extraction (DRm) (38 $\pm 1 \mathrm{GPa})(\mathrm{P}>0.05)$, while mechanical extraction however gave rise to a significantly reduced E1-modulus of the composite impregnated with scutched dew retted fibers (DRs) $(35 \pm 2 \mathrm{GPa})(\mathrm{P} \leq 0.005)$. Remarkably, composites reinforced with FT showed only a E1-modulus of $31 \pm 3$ GPa $(P \leq 0.001)$. Baley et al. [37] found a tensile modulus of $26 \pm 2 \mathrm{GPa}$ for a unidirectional flax-epoxy composite with FlaxTape as flax material and a similar fiber volume fraction, which is in line with the measured tensile modulus of the FT-epoxy composite in this study.

Enzymatic treatments with pectinases and hemicellulases clearly showed improvements in the tensile modulus of the fiber reinforced composites (ranging from 41 to $44 \mathrm{GPa}$ ) compared to the GR fiber composites, with significant differences for $\mathrm{Sc}$ and $\mathrm{XTI}$ treatment $(\mathrm{P} \leq 0.002)$. Among enzymatic treatments, no significant differences could be observed and they were not significantly different from EDTA treatment either ( $P>0.05)$. Coroller et al. [38] and Mahboob et al. [39] reported unidirectional flaxepoxy composites with a Young's modulus ranging from 11 to $35 \mathrm{GPa}$. Obtained stiffness in this study were hence rather high.

Figure 2. Normalized longitudinal E1- and E2-modulus of (A) composites impregnated with reference fiber materials and with fibers extracted from enzymatically treated flax [GPa] and (B) back-calculated values for fibers [GPa] 
When looking at the ratio of E2/E1, stiffness was retained for about 92 to $95 \%$ in all cases, with exception of mechanically extracted DRs (86\%) and FT (78\%). Preservation of the stiffness in the manually extracted composite materials was hence very successful. In literature, drops of $31 \%$ have been observed between E1- and E2-moduli calculations [40]. A possible explanation for the preservation of stiffness can be due to less damage induced in the fibers. Upon common mechanical extraction, damage may be initiated (especially in the weak pectin rich middle lamellae) after which likely more easily shear occurs at higher stress. This is an interesting observation, which warrants future research towards extraction processes with more mimic of the manual extraction methodology.

E-moduli of composites were back-calculated to the moduli of the fibers according to the rule of mixture and are illustrated in Figure 2B. Back-calculated fiber properties are included instead of measured fiber properties, since previous research indicated there was no correlation between fiber properties as determined in single fiber tests and composite properties $[9,29,33,41,42]$. The explanation given for this is that in a composite the matrix can partially repair defects between the elementary fibers. In previous research (Bensadoun et al. [40]), a back-calculated fiber modulus (E1) of $59.8 \pm 2.4 \mathrm{GPa}$ for hackled long flax fibers from the same batch was observed as an average between five different laboratories. Thomason et al. [43] reported untreated flax fibers with a tensile modulus of $45.9 \pm 2.6 \mathrm{GPa}$. Measurements of fibers with shorter gauge lengths during tensile tests tend to give higher properties in case of elementary fibers [39]. Even though this gauge length theory does not apply for technical fibers, tested gauge lengths were $15 \mathrm{~mm}$ in each study [40,43], as well as in this study. According to Lamy et al. $[44,45]$, stiffness is inversely proportional to the fiber diameter [39]. However, in this study, the finest fibers observed from FT did not result in the best tensile stiffness (62.1 $\pm 5.1 \mathrm{GPa})$. In literature, a backcalculated fiber tensile stiffness of $43 \pm 5 \mathrm{GPa}$ was reported for FlaxTape-epoxy unidirectional composites [29]. The tensile modulus for FT composites obtained in this study is thus higher than values reported in literature. In the review of Pickering et al. [1], Young's moduli of flax fibers of 27 to 80 GPa were summarized. Stiffness values between 40 and $60 \mathrm{GPa}$ are mostly observed for technical fibers, where stiffness of 60 to $80 \mathrm{GPa}$ is attributed to elementary fibers. Hence, fiber stiffness of approximately 80 to 85 GPa determined in this study are rather high. Given the lower values of the mechanically extracted 
fibers in this research, it is hypothesized that the manual extraction method used has managed to preserve the integrity of the technical fibers.

Due to the high tensile moduli observed, the extensometer was verified by a hard calibration. Even though hard calibration confirmed the correct functioning of the extensometer, Digital Image Correlation (DIC) was performed as well. A digital camera with a spatial resolution of $96 \mathrm{dpi}$ was used to record the speckle pattern applied to the sample. The distance between composite sample and camera was $1 \mathrm{~m}$. During the test, subsequent images and force registration were taken with an interval of $150 \mathrm{~ms}$ [46]. Images were further analyzed with VIC-2D 2009 software to calculate the strain. This method was performed simultaneously in combination with the extensometer to exclude any variability in the composite sample. No significant difference could be found between the measured tensile moduli and also confirmed earlier measured results (results not shown).

Next to the tensile modulus, tensile strength or failure stress of the composites was determined as well to evaluate the mechanical performance. Normalized tensile strength of the composites is illustrated in Figure $3 \mathrm{~A}$. Figure 3B shows the results of the back-calculated failure strength of the fibers, employing the standard rule of mixtures taking into account the stress in the matrix at the failure strain of the fibers [29].

GR resulted in composites with a tensile strength of $404 \pm 26 \mathrm{MPa}$. Water treatment delivered fibers resulting in composites with the highest tensile strength of $463 \pm 31 \mathrm{MPa}$. Compared to the GR material however, water and EDTA reference treatments, DRm and all enzymatic treatments showed no significant difference in tensile strength $(P>0.05)$. However, a significantly lower tensile strength was observed for composites impregnated with DRs $(315 \pm 15 \mathrm{MPa})(\mathrm{P} \leq 0.005)$ and $\mathrm{FT}(324 \pm 32 \mathrm{MPa})(\mathrm{P} \leq 0.05)$, compared to GR. FT and to a lesser extend DRs are mechanically processed flax fibers, leading to more fiber damage.

Another factor that could possibly affect the stiffness and strength of the composites is the fiber orientation or degree of alignment, since fibers are the carriers of stress and load [47]. The width of the composite specimens was kept limited in order to reduce possible changes in fiber orientation. Due to the manual extraction of enzymatically treated flax, the changes in fiber orientations will be rather limited. The highest degree of misalignment was observed for DRs, which may explain the rather low mechanical 
properties. However, in case of FT, alignment is very high, which cannot be correlated to the observed longitudinal properties.

The FT-epoxy composite from the research of Baley et al. [37] possessed a tensile strength of $408 \pm 36$ MPa, while the study of Hendrickx et al. [29] reported FlaxTape-epoxy composites with a tensile strength of about $380 \pm 20 \mathrm{MPa}$ (normalized to a fiber volume fraction of $60 \%$, this strength should be however higher than our measured strength). Mahboob et al. [39] and Corroler et al. [38] described several flaxepoxy composites with variating tension strengths of 113 to $408 \mathrm{MPa}$. These results are in line with the findings presented above for the modulus. Again the mechanical extraction seems to have created some damage inside the technical fibers, in contrast to the manual extraction method. The enzymatic treatments do not seem to result in an increase in strength, where there was a positive effect on the modulus. Also, benefits in ease of extraction were seen when enzymatic treatments were applied on flax stems [10].

Figure 3. Normalized longitudinal tensile strength of $(A)$ composite [MPa] to a fiber volume fraction of $50 \%$ and $(B)$ back-calculated fiber tensile strength [MPa]

In Figure 3B, back-calculated fiber tensile strengths from the composite tensile tests are shown. Backcalculated tensile strength of GR amounted to $776 \pm 50 \mathrm{MPa}$ and increased to $891 \pm 59 \mathrm{MPa}$ for fibers extracted after water treatment. In accordance with the results of the back-calculated tensile modulus of the fibers, significantly lower results were obtained for back-calculated tensile strengths of DRs fibers (602 $\pm 30 \mathrm{MPa})(\mathrm{P} \leq 0.005)$ and FT $(611 \pm 60 \mathrm{MPa})(\mathrm{P} \leq 0.01)$. With the exception of $\mathrm{DRs}$ and $\mathrm{FT}$, all other treatments resulted in statistically comparable tensile properties compared to GR $(P>0.05)$. Mohanty et al. [48] summarized tensile strengths of flax fibers in literature, ranging between 345 and $1100 \mathrm{MPa}$ for a wide variety of fibers, ranging from elementary fibers to coarse technical fibers. Tensile strengths determined within this study fit within this range but are again rather high, certainly in direct comparison with the mechanically extracted fibers.

Study of the composites performance showed that the manual extraction of fibers enabled us to avoid fiber damage. With tensile strengths of $800 \mathrm{MPa}$, a certain maximum has been reached for technical 
fibers. No significantly different results were obtained for composites impregnated with fibers extracted after water treatment, EDTA treatment or enzymatic treatments. These treatments however may have realized a removal of weak pectin from the outer surface of the technical fibers.

\subsection{Transversal properties of composites}

Evaluation of longitudinal tensile properties elucidates more on the potential of enzymatic treatments but no significantly higher properties were observed compared to the reference EDTA treatment. In comparison with DRm fibers, somewhat better tensile properties were observed. However, not only longitudinal properties are important, also transversal properties should be studied. Figure 4 illustrates the results of the determination of the transversal bending strength of composites after three-point bending tests.

Figure 4. Transverse bending strength [MPa] of composites reinforced with reference fiber materials and fibers extracted after enzymatic treatments

GR-epoxy composites were characterized with a transverse bending strength of $17.2 \pm 2.3 \mathrm{MPa}$ (Figure 4). Compared to the GR-epoxy composites, composites impregnated with DRm fibers and Sc treated flax fibers were not significantly different with bending strengths of $19.8 \pm 3.4 \mathrm{MPa}$ and $21.3 \pm 2.7 \mathrm{MPa}$, respectively $(P>0.05)$. Water and EDTA treatment resulted in fiber composites with significantly higher transverse bending strength compared to GR composites $(P \leq 0.05)$, as well as all enzymatic treatments with exception of Sc. Bending strength of composites based on fibers after water, EDTA and all enzymatic treatments and DRs fibers were not statistically different $(P>0.05)$. FT-epoxy composites on the other hand possessed a very high transverse bending strength of $40.9 \pm 1.6 \mathrm{MPa}$ compared to all other composites. Hendrickx et al. [29] determined flexural properties of flax-epoxy composites and found a transverse bending strength of $37 \mathrm{MPa}$ for FlaxTape-epoxy composites and 24 to $30 \mathrm{MPa}$ for naturally retted flax fiber-epoxy composites. Given the fineness results, a high transverse strength was expected for the FT composite, since flexural strength is highly dependent on fiber fineness and purity [29]. Furthermore, the high degree of alignment of FT fibers may have had a positive impact on the transverse bending properties as well. 
It should be noted that GR-epoxy composites were characterized with high tensile properties, even though lower properties were expected since fibers are coarser and impure. A mechanical extraction necessary to loosen the fibers would probably imply more fiber damage [49]. The manual extraction procedure however applied within this research limited fiber damage. The manual extraction on the other hand left fewer impurities (f.e. shives) on the fiber, resulting in the promising tensile composite properties. Impurities between fibers are known to cause stress regions in the composite which lead to early fracture [49]. Furthermore, it is expected that additional hackling induces even more fiber damage than when only scutching is applied. Concerning tensile properties, almost no differences could be observed between scutching (DRs) and hackling (FT). Transverse bending strength however excelled for FT-composites, implying that the further refining of the fibers has more effect on the composite performance than the induced fiber damage [49].

Based on tensile properties, no enzymatic treatment came forward as exceptional but every enzymatic treatment did give competitive results illustrating the potential of enzymatic treatments as an alternative for dew retting. Nevertheless, the importance of EDTA is also addressed. In the future, strategic combinations of the pure enzyme activities should be studied to investigate possible synergies between enzymes and further improvement of mechanical properties.

\subsection{Fracture surface analysis of composites after bending tests}

The fracture surfaces of the composites after three-point bending tests were analyzed with SEM. Figure 5 gives a schematic drawing of the composite specimen undergoing the three-point bending test indicating the location of the analyzed fracture surface.

Figure 5. Schematic drawing of composite specimen undergoing three-point bending testing indicating the location of the fracture surface analyzed with SEM

With fracture surface analysis, more information might be obtained about the reason of failure: fiber failure, matrix failure or fiber-matrix interface failure. A SEM image is shown in Figure 6 for GR-epoxy composites. 
Figure 6. SEM analysis of the fracture surface of GR-epoxy composite after three-point bending test (200x). The scale bar represents $100 \mu \mathrm{m}$

Figure 6 illustrates that in case of GR fibers, fiber bundles were still closely together. Since no separation between fibers took place within the fiber bundle, the epoxy matrix was not able to penetrate through the fibers. The fiber-matrix surface was hence much smaller compared to fibers with a higher fineness. The limited surface results in restricted interface possibilities, leading to the lower mechanical properties observed for GR-epoxy composites. In flax-epoxy composites, the flax-epoxy bond is often stronger than internal bonding between elementary fibers, which is why coarse fibers give lower transverse bending strength due to more chance on internal fiber failure. SEM images of composites based on fibers extracted after water, EDTA and PAn treatment are illustrated in Figure 7.

Figure 7. SEM analysis of fracture surfaces of three-point bending test composite samples with fibers treated with (A) water (96x), (B) EDTA (98x) and (C) PAn (101x). The scale bar represents $200 \mu \mathrm{m}$

Looking at the fracture surface of composites impregnated with water treated fibers (Figure 7A), fracture may have occurred by failure of the matrix material. Fiber bundles were not separated by water treatment. In comparison to EDTA treatment (Figure 7B), a separation of elementary fibers within the fiber bundle can be noticed, as well as after PAn treatment (Figure 7C). Since this is the fracture surface, it is possible that fracture occurred trough the technical fiber, resulting in separation of the fiber. PAn treatment showed more fibrillation within the fiber bundles and fewer impurities were observed on the fiber surface after PAn treatment, demonstrating the importance and profit of the utilization of enzymes.

\subsection{Characterization of moisture absorption}

EMC and diffusion coefficients were determined for composites reinforced with untreated fibers and enzymatically treated fibers to investigate the effect of enzymatic treatments on moisture absorption. Moisture absorption could lead to a degradation of fiber tensile properties [34] while swelling might generate internal stresses in the fiber-matrix interface [50]. Enzymes affecting pectin and hemicellulose structures in the fiber degrade the hydrophilic substances present in the surrounding network of the 
cellulose nanofibrils and may thus be beneficial to reduce moisture absorption. EMC and diffusion coefficients are illustrated in Tabel 4.

Tabel 4. Moisture absorption results of composites impregnated with enzymatically treated fibers compared to GR flax fiber composites: equilibrium moisture content (\%) and diffusion coefficient $\left(\mathrm{mm}^{2} / \mathrm{s}\right)$

A significant decrease in EMC of composites was observed for all enzymatic treatments compared to the starting material, with exception of NS. Among pectinases, PAn treatment resulted in fiber composites with a significantly lower EMC value. When looking at the diffusion coefficient, GR fiber composites showed a significantly higher value compared to the composites based on fibers after enzymatic treatment. Pectinases were observed to result in a higher reduction of the diffusion coefficient compared to hemicellulases. Concerning moisture sensitivity, most optimal results are obtained for composites with fibers extracted after PAn treatment.

Water absorption of composites was tested by George et al. [11] by immersion of composites in water. No EMC or diffusion coefficient was calculated, but water absorption tests revealed that the highest absorption reduction was obtained for composites impregnated with fibers treated with polygalacturonase and xylanase+cellulase. Polygalacturonase treatment clearly causes an important effect and shows promising potential for the application in retting flax. Assarar et al. [28] determined equilibrium water uptake and diffusion coefficient for flax fiber-epoxy composites (11 ply unidirectional laminates) and compared it with glass fiber-epoxy composites. A diffusion coefficient of $10.51 \times 10^{-7}$ $\mathrm{mm}^{2} / \mathrm{s}$ was reported for the flax fiber-epoxy composites, along with a moisture water uptake of $13.50 \%$ [28]. In contrast, glass fiber-epoxy composites showed only a moisture water uptake of $1.05 \%$ [28]. Even though a higher diffusion coefficient was determined in this study, the first results concerning the EMC of composites with fibers extracted after enzymatic treatment showed promising improvements. To unravel however the effect on moisture sensitivity in comparison with other fiber references, a separate study is necessary which is subject of future work.

\section{Conclusions}


This study investigated the mechanical performance of composites reinforced with fibers extracted after enzymatic treatments, along with the fiber fineness, moisture absorption of composites and fracture surface analysis. Longitudinal and transverse composite properties demonstrated the potential of enzymatic treatments as an alternative for the traditional dew retting process. All enzymatic treatments showed promising tensile strength and stiffness results but were not significantly different amongst each other. Polygalacturonase (PAn) treatments resulted in the highest reductions in moisture absorption by composites. This study illustrated that EDTA is an important factor in the retting process and appears to perform almost as successful as enzymatic treatments. Enzymatic treatments however involve high controllability of the retting process. Furthermore, a less severe mechanical post-treatment will be necessary, implying less fiber damage will occur and a higher fiber yield will be obtained. Very interestingly, this research suggests that improvements in the extraction process, mimicking what was achieved after manual extraction, could lead to less fiber damage and significantly increased flax fiber modulus (from 60 to more than $80 \mathrm{GPa}$ ) and strength (from 600 to $800 \mathrm{MPa}$ ). Hence, the promising potential of NFRC should be fully and further explored in order to build the sustainable future of tomorrow.

\section{Acknowledgements}

This work was supported by the Flemish Agency for Innovation and Entrepreneurship (Vlaams Agenschap Innoveren \& Ondernemen, VLAIO) [grant number 141387]. The authors gratefully want to thank Verhalle and Vanacker Rumbeke for providing flax as well as Elmar Janser from Novozymes for his support.

\section{References}

[1] Pickering KL, Efendy MGA, Le TM. A review of recent developments in natural fibre composites and their mechanical performance. Compos Part A Appl Sci Manuf 2016;83:98-112.

[2] CELC. Composite Applications 2010. http://www.europeanflax.com/eng/technique/19-secteursd-application.

[3] Akin DE, Gamble GR, Morrison WH, Rigsby LL, Dodd RB. Chemical and structural analysis of fibre 
and core tissues from flax. J Sci Food Agric 1996;72:155-65.

[4] Sitohang R. Effect of technical fiber strength, fineness and purity on the performance of flax composites. KU Leuven, Belgium, 2015.

[5] Sharma HSS, Faughey G, Lyons G. Comparison of physical, chemical, and thermal characteristics of water-, dew-, and enzyme-retted flax fibers. J Appl Polym Sci 1999;74:139-43. doi:10.1002/(SICI)1097-4628(19991003)74:1<139::AID-APP17>3.0.CO;2-E.

[6] De Prez J, Van Vuure AW, Ivens J, Aerts G, Van de Voorde I. Evaluation of the extraction efficiency of enzymatically treated flax fibers. In: Fangueiro R, Rana S, editors. Adv. Nat. Fibre Compos., vol. 1. 1st ed., Springer International Publishing; 2018, p. 37-49. doi:https://doi.org/10.1007/978-3-319-64641-1.

[7] Martin N, Mouret N, Davies P, Baley C. Influence of the degree of retting of flax fibers on the tensile properties of single fibers and short fiber/polypropylene composites. Ind Crops Prod 2013;49:755-67. doi:10.1016/j.indcrop.2013.06.012.

[8] Pickering KL, Beckermann GW, Alam SN, Foreman NJ. Optimising industrial hemp fibre for composites. Compos Part A Appl Sci Manuf 2007;38:461-8.

doi:10.1016/j.compositesa.2006.02.020.

[9] De Prez J, Van Vuure AW, Ivens J, Aerts G, Van de Voorde I. Enzymatic treatment of flax for use in composites. Biotechnol Reports 2018;20:e00294. doi:10.1016/j.btre.2018.e00294.

[10] De Prez J, Van Vuure AW, Ivens J, Aerts G, Van de Voorde I. Effect of enzymatic treatment of flax on ease of fiber extraction and chemical composition. BioResources 2019:1-16.

[11] George M, Mussone PG, Alemaskin K, Chae M, Wolodko J, Bressler DC. Enzymatically treated natural fibres as reinforcing agents for biocomposite material: mechanical, thermal, and moisture absorption characterization. J Mater Sci 2016;51:2677-86. doi:10.1007/s10853-0159582-z. 
[12] Stuart T, Liu Q, Hughes M, McCall RD, Sharma HSS, Norton A. Structural biocomposites from flax - Part I: Effect of bio-technical fibre modification on composite properties. Compos Part A Appl Sci Manuf 2006;37:393-404. doi:10.1016/j.compositesa.2005.06.002.

[13] Evans JD, Akin DE, Foulk JA. Flax-retting by polygalacturonase-containing enzyme mixtures and effects on fiber properties. J Biotechnol 2002;97:223-31.

[14] Akin DE, Condon B, Sohn M, Foulk JA, Dodd RB, Rigsby LL. Optimization for enzyme-retting of flax with pectate lyase. Ind Crops Prod 2007;25:136-46.

doi:https://doi.org/10.1016/j.indcrop.2006.08.003.

[15] Akin DE, Foulk JA, Dodd RB, McAlister DD. Enzyme-retting of flax and characterization of processed fibers. J Biotechnol 2001;89:193-203.

[16] Foulk JA, Akin DE, Dodd RB. Influence of pectinolytic enzymes on retting effectiveness and resultant fiber properties. BioResources 2008;3:155-69.

[17] Brunsek R, Tarbuk A, Butorac J. Bio-innovative flax retting. 8th Cent. Eur. Conf. Fiber-Grade Polym. Chem. Fibers Spec. Text., Zagreb, Croatia: 2015, p. 6.

[18] Masseteau B, Michaud F, Irle M, Roy A, Alise G. An evaluation of the effects of moisture content on the modulus of elasticity of a unidirectional flax fiber composite. Compos Part A Appl Sci Manuf 2014;60:32-7. doi:10.1016/j.compositesa.2014.01.011.

[19] Le Duigou A, Davies P, Baley C. Seawater ageing of flax/poly(lactic acid) biocomposites. Polym Degrad Stab 2009;94:1151-62. doi:10.1016/j.polymdegradstab.2009.03.025.

[20] Célino A, Fréour S, Jacquemin F, Casari P. Characterization and modeling of the moisture diffusion behavior of natural fibers. J Appl Polym Sci 2013;130:297-306. doi:10.1002/APP.39148.

[21] Célino A, Fréour S, Jacquemin F, Casari P. The hygroscopic behavior of plant fibers: a review. Front Chem 2014;2:1-12. doi:10.3389/fchem.2013.00043. 
[22] Célino A, Fréour S, Jacquemin F, Casari P. Study of the Diffusion Behavior of Natural Fibers. 15th Eur. Conf. Compos. Mater., Venice, Italy: 2012, p. 1-8.

[23] George M, Mussone PG, Abboud Z, Bressler DC. Characterization of chemically and enzymatically treated hemp fibres using atomic force microscopy and spectroscopy. Appl Surf Sci 2014;314:1019-25. doi:10.1016/j.apsusc.2014.06.080.

[24] Placet V, Cisse O, Boubakar ML. Influence of environmental relative humidity on the tensile and rotational behaviour of hemp fibres. J Mater Sci 2012;47:3435-46. doi:10.1007/s10853-0116191-3.

[25] Alix S, Philippe E, Bessadok A, Lebrun L, Morvan C, Marais S. Effect of chemical treatments on water sorption and mechanical properties of flax fibres. Bioresour Technol 2009;100:4742-9. doi:10.1016/j.biortech.2009.04.067.

[26] Alix S, Lebrun L, Marais S, Philippe E, Bourmaud a., Baley C, et al. Pectinase treatments on technical fibres of flax: Effects on water sorption and mechanical properties. Carbohydr Polym 2012;87:177-85. doi:10.1016/j.carbpol.2011.07.035.

[27] Pejic BM, Kostic MM, Skundric PD, Praskalo JZ. The effects of hemicelluloses and lignin removal on water uptake behavior of hemp fibers. Bioresour Technol 2008;99:7152-9. doi:10.1016/j.biortech.2007.12.073.

[28] Assarar M, Scida D, Mahi A El, Poilâne C, Ayad R. Influence of water ageing on mechanical properties and damage events of two reinforced composite materials : Flax - fibres and glass fibres. Mater Des 2011;32:788-95. doi:10.1016/j.matdes.2010.07.024.

[29] Hendrickx K, Romian RD, Goedemé T, Van Vuure AW, Ivens J. Rapid and Effective Methods for the Screening of Flax Fibres for Composite Applications. Proc. 20th Int. Conf. Compos. Mater., Copenhagen, Denmark: 2015, p. 1-9.

[30] ASTM INTERNATIONAL. ASTM D3039/D3039M: Standard test method for tensile properties of 
polymer matrix composite materials. 2008. doi:10.1520/D3039.

[31] ASTM INTERNATIONAL. ASTM D7264/D7264M: Standard Test Method for Flexural Properties of Polymer Matrix Composite Materials. 2007.

[32] ASTM INTERNATIONAL. ASTM D5229/D5229M: Standard Test Method for Moisture Absorption Properties and Equilibrium Conditioning of Polymer Matrix Composite Materials. 2004.

[33] Saleem Z, Rennebaum H, Pudel F, Grimm E. Treating bast fibres with pectinase improves mechanical characteristics of reinforced thermoplastic composites. Compos Sci Technol 2008;68:471-6. doi:10.1016/j.compscitech.2007.06.005.

[34] Yan L, Chouw N, Jayaraman K. Flax fibre and its composites - A review. Compos Part B Eng 2014;56:296-317. doi:10.1016/j.compositesb.2013.08.014.

[35] Akin DE, Slomczynski D, Rigsby LL, Eriksson K-EL. Retting flax with endopolygalacturonase from Rhizopus oryzae. Text Res J 2002;72:27-34. doi:10.1177/004051750207200105.

[36] Biagiotti J, Puglia D, Kenny JM. A review on natural fibre-based composites Part I: Structure, processing and properties of vegetable fibres. J Nat Fibers 2004;1:37-68. doi:10.1300/J395v01n02_04.

[37] Baley C, Lan M, Bourmaud A, Le Duigou A. Compressive and tensile behaviour of unidirectional composites reinforced by natural fibres: Influence of fibres (flax and jute), matrix and fibre volume fraction. Mater Today Commun 2018;16:300-6. doi:10.1016/j.mtcomm.2018.07.003.

[38] Coroller G, Lefeuvre A, Le Duigou A, Bourmaud A, Ausias G, Gaudry T, et al. Effect of flax fibres individualisation on tensile failure of flax/epoxy unidirectional composite. Compos Part A Appl Sci Manuf 2013;51:62-70. doi:10.1016/j.compositesa.2013.03.018.

[39] Mahboob Z, El Sawi I, Zdero R, Fawaz Z, Bougherara H. Tensile and compressive damaged response in Flax fibre reinforced epoxy composites. Compos Part A Appl Sci Manuf 2017;92:118- 
33. doi:10.1016/j.compositesa.2016.11.007.

[40] Bensadoun F, Verpoest I, Baets J, Müssig J, Graupner N, Davies P, et al. Impregnated fibre bundle test for natural fibres used in composites. J Reinf Plast Compos 2017;36:942-57. doi:10.1177/0731684417695461.

[41] Acera Fernández J, Le Moigne N, Caro-Bretelle AS, El Hage R, Le Duc A, Lozachmeur M, et al. Role of flax cell wall components on the microstructure and transverse mechanical behaviour of flax fabrics reinforced epoxy biocomposites. Ind Crops Prod 2016;85:93-108. doi:10.1016/j.indcrop.2016.02.047.

[42] Shah DU, Nag RK, Clifford MJ. Why do we observe significant differences between measured and 'back-calculated' properties of natural fibres? Cellulose 2016;23:1481-90. doi:10.1007/s10570016-0926-x.

[43] Thomason JL, Carruthers J, Kelly J, Johnson G. Fibre cross-section determination and variability in sisal and flax and its effects on fibre performance characterisation. Compos Sci Technol 2011;71:1008-15. doi:10.1016/j.compscitech.2011.03.007.

[44] Lamy B, Pomel C. Influence of fiber defects on the stiffness properties of flax fibers-epoxy composite materials. J Mater Sci Lett 2002;21:1211-3. doi:10.1023/A:1016524619867.

[45] Lamy B, Baley C. Stiffness prediction of flax fibers-epoxy composite materials. J Mater Sci Lett 2000;19:979-80. doi:10.1023/A:1006776423764.

[46] Depuydt D, Hendrickx K, Biesmans W, Ivens J, Van Vuure AW. Digital image correlation as a strain measurement technique for fibre tensile tests. Compos Part A Appl Sci Manuf 2017;99:76-83. doi:10.1016/j.compositesa.2017.03.035.

[47] Khan MZR, Srivastava SK, Gupta MK. Tensile and flexural properties of natural fiber reinforced polymer composites : A review. J Reinf Plast Compos 2018;37:1435-55. doi:10.1177/0731684418799528. 
[48] Mohanty AK, Misra M, Hinrichsen G. Biofibres, biodegradable polymers and biocomposites: An overview. Macromol Mater Eng 2000;276-277:1-24. doi:10.1002/(SICI)14392054(20000301)276:1<1::AID-MAME1>3.0.CO;2-W.

[49] Van de Weyenberg I, Ivens J, De Coster A, Kino B, Baetens E, Verpoest I. Influence of processing and chemical treatment of flax fibres on their composites. Compos Sci Technol 2003;63:1241-6. doi:10.1016/S0266-3538(03)00093-9.

[50] Madsen B. Properties of Plant Fibre Yarn Polymer Composites. PhD-Thesis. Technical University of Denmark, 2004. 
Figure 1. Fineness distribution curve of $(A) G R$ and (B) FT...

Figure 2. Normalized longitudinal E1- and E2-modulus of (A) composites impregnated with reference fiber materials and with fibers extracted from enzymatically treated flax [GPa] and (B) back-calculated values for fibers [GPa]

Figure 3. Normalized longitudinal tensile strength of $(A)$ composite [MPa] to a fiber volume fraction of $50 \%$ and (B) back-calculated fiber tensile strength [MPa]

Figure 4. Transverse bending strength [MPa] of composites reinforced with reference fiber materials and fibers extracted after enzymatic treatments

Figure 5. Schematic drawing of composite specimen undergoing three-point bending testing indicating the location of the fracture surface analyzed with SEM .....

Figure 6. SEM analysis of the fracture surface of GR-epoxy composite after three-point bending test (200x). The scale bar represents $100 \mu \mathrm{m}$

Figure 7. SEM analysis of fracture surfaces of three-point bending test composite samples with fibers treated with (A) water (96x), (B) EDTA (98x) and (C) PAn (101x). The scale bar represents $200 \mu \mathrm{m}$

Table 1. References and specifications concerning origin and extraction method 5

Table 2. Overview of different treatments of flax (fibers were all manually extracted) .............. 6 Table 3. Results of analysis of fiber fineness with average, median and maximum value as well as percentages of fiber widths higher than $300 \mu \mathrm{m}$ and smaller than $100 \mu \mathrm{m}$.

Tabel 4. Moisture absorption results of composites impregnated with enzymatically treated fibers compared to GR flax fiber composites: equilibrium moisture content (\%) and diffusion coefficient $\left(\mathrm{mm}^{2} / \mathrm{s}\right)$ 

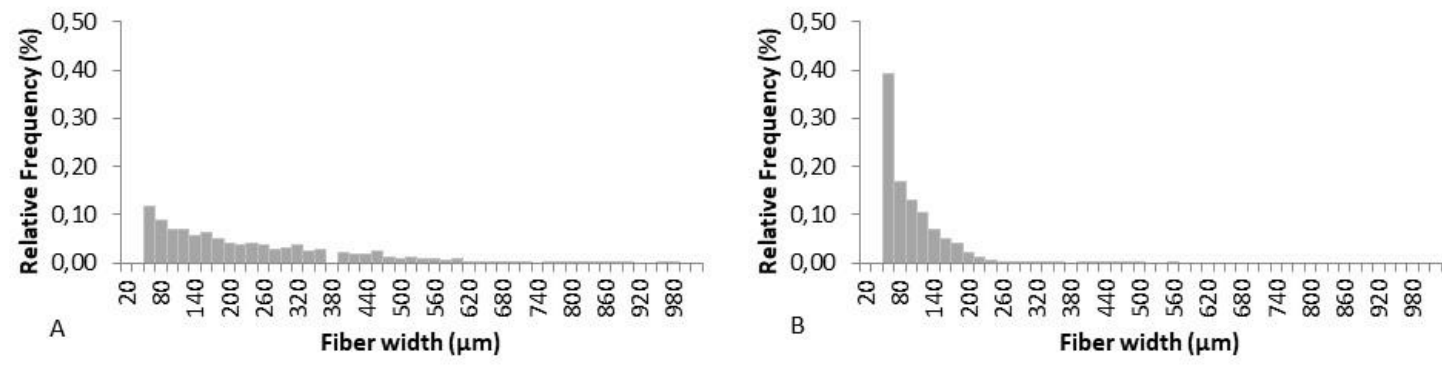

Figure 1. Fineness distribution curve of (A) green fibers and (B) FlaxTape 

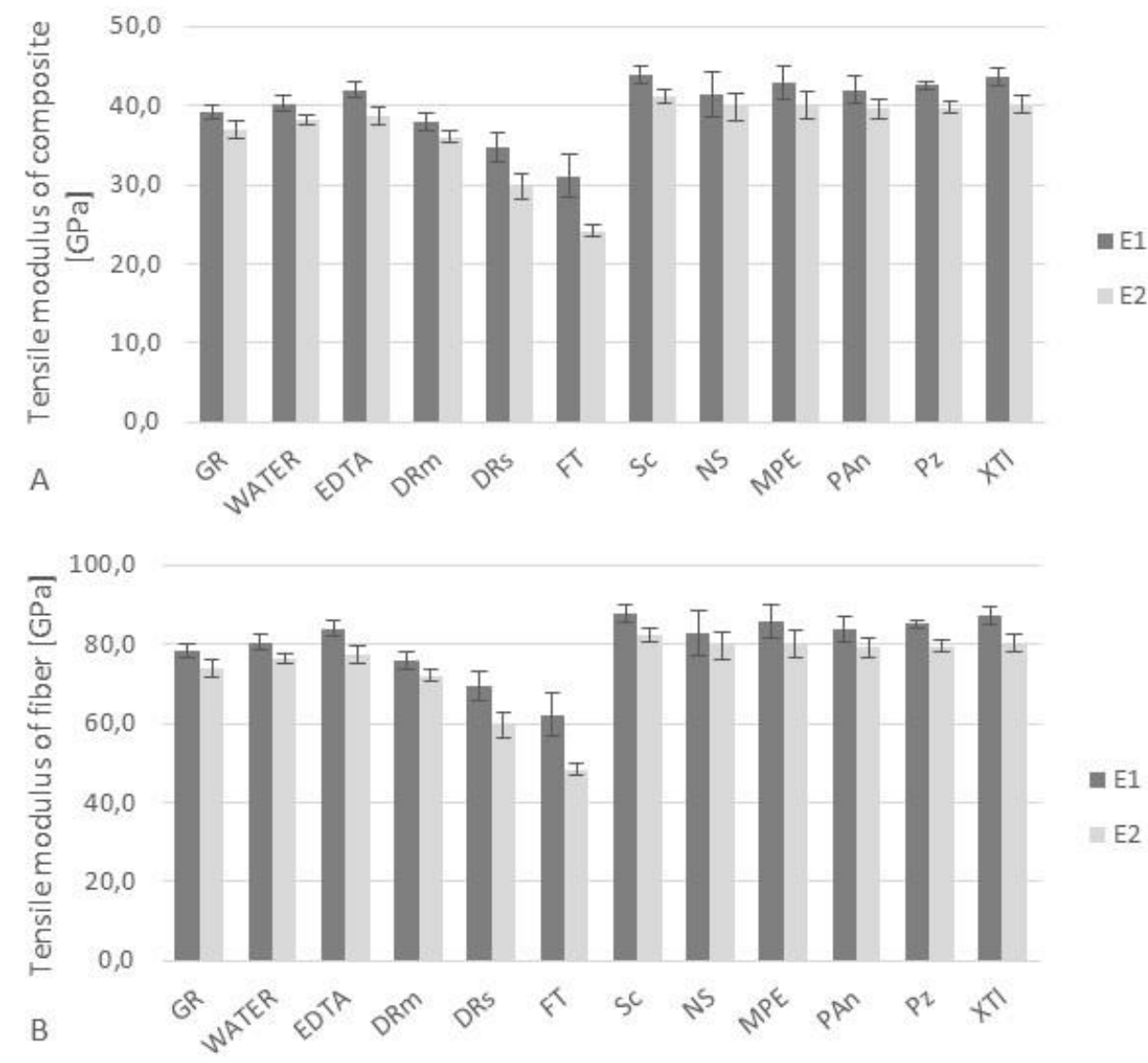

Figure 2. Normalized longitudinal E1- and E2-modulus of $(A)$ composites impregnated with reference fiber materials and with fibers extracted from enzymatically treated flax [GPa] and (B) back-calculated values for fibers [GPa] 

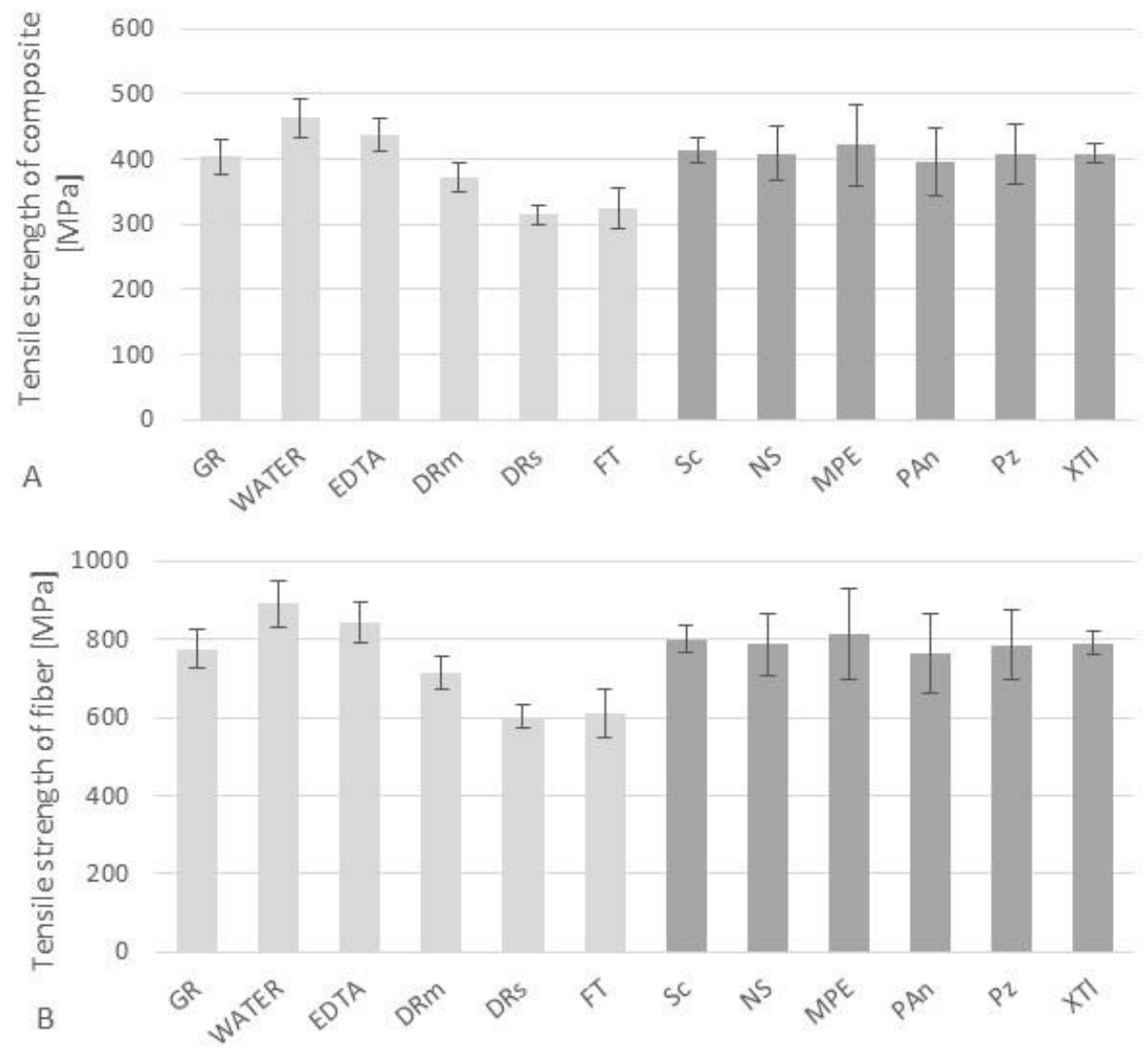

Figure 3. Normalized longitudinal tensile strength of $(A)$ composite $[\mathrm{MPa}]$ to a fiber volume fraction of $50 \%$ and $(B)$ back-calculated fiber tensile strength [MPa] 


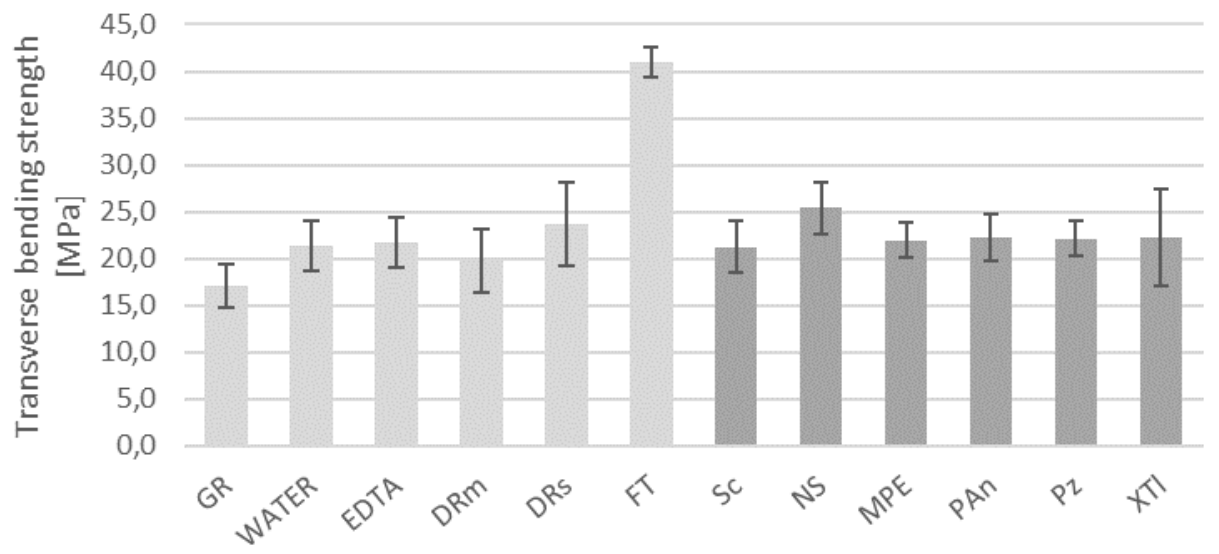

Figure 4. Transverse bending strength [MPa] of composites reinforced with reference fiber materials and fibers extracted after enzymatic treatments 


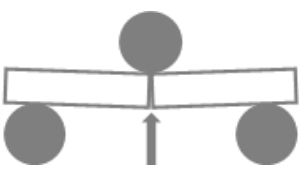

Figure 5. Schematic drawing of composite specimen undergoing three-point bending testing indicating the location of the fracture surface analyzed with SEM 


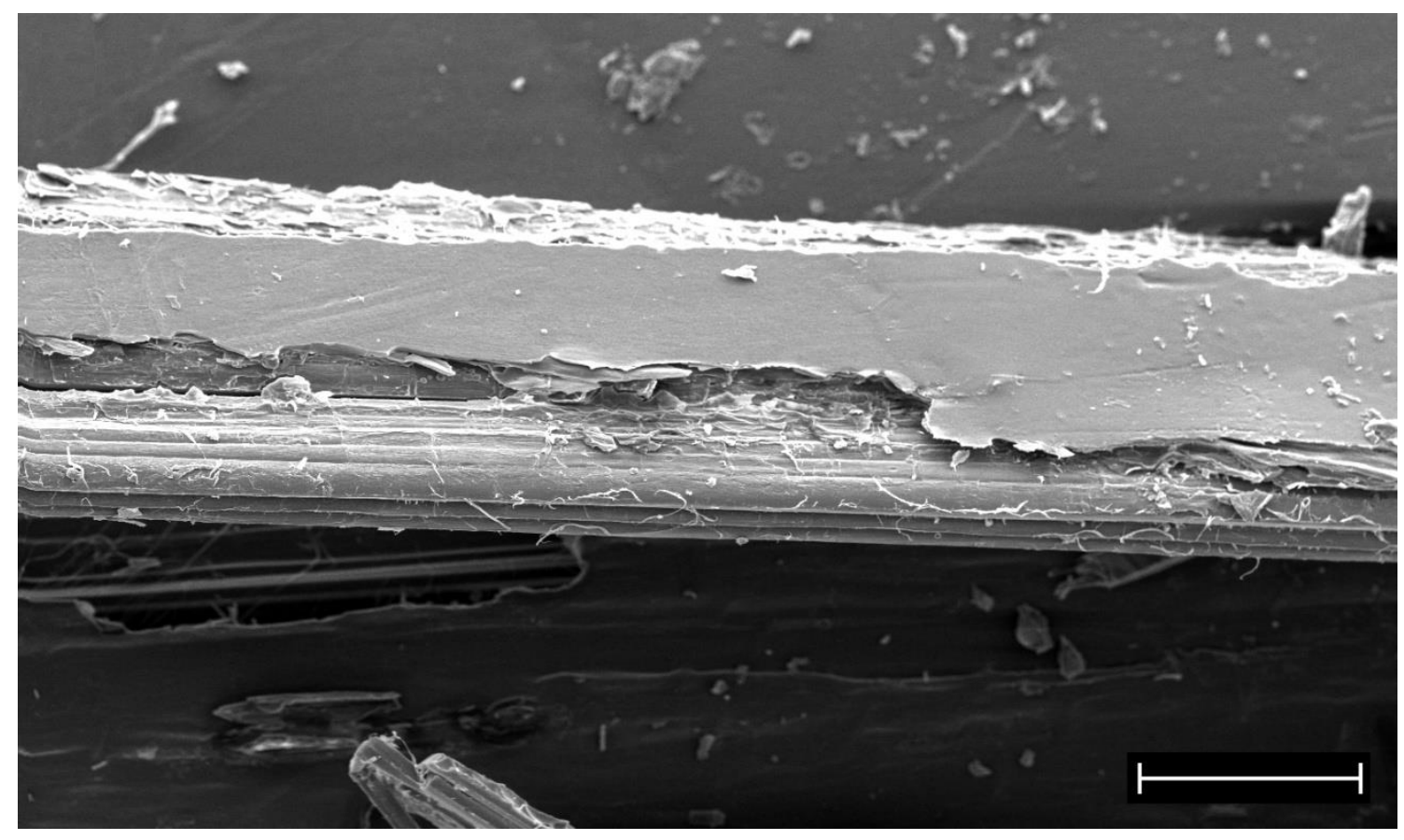

Figure 6. SEM analysis of the fracture surface of GR-epoxy composite after three-point bending test (200x). The scale bar represents $100 \mu \mathrm{m}$ 


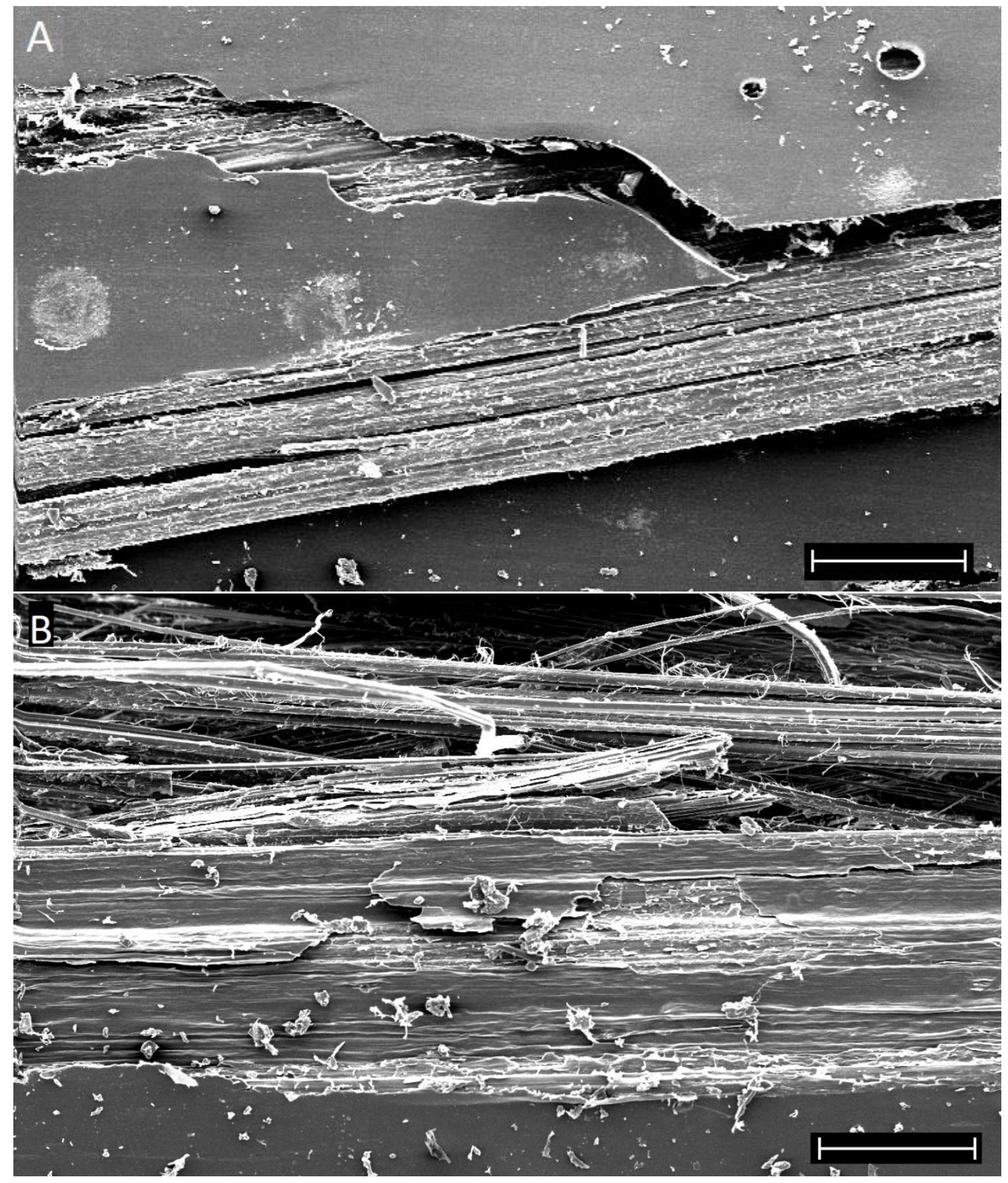




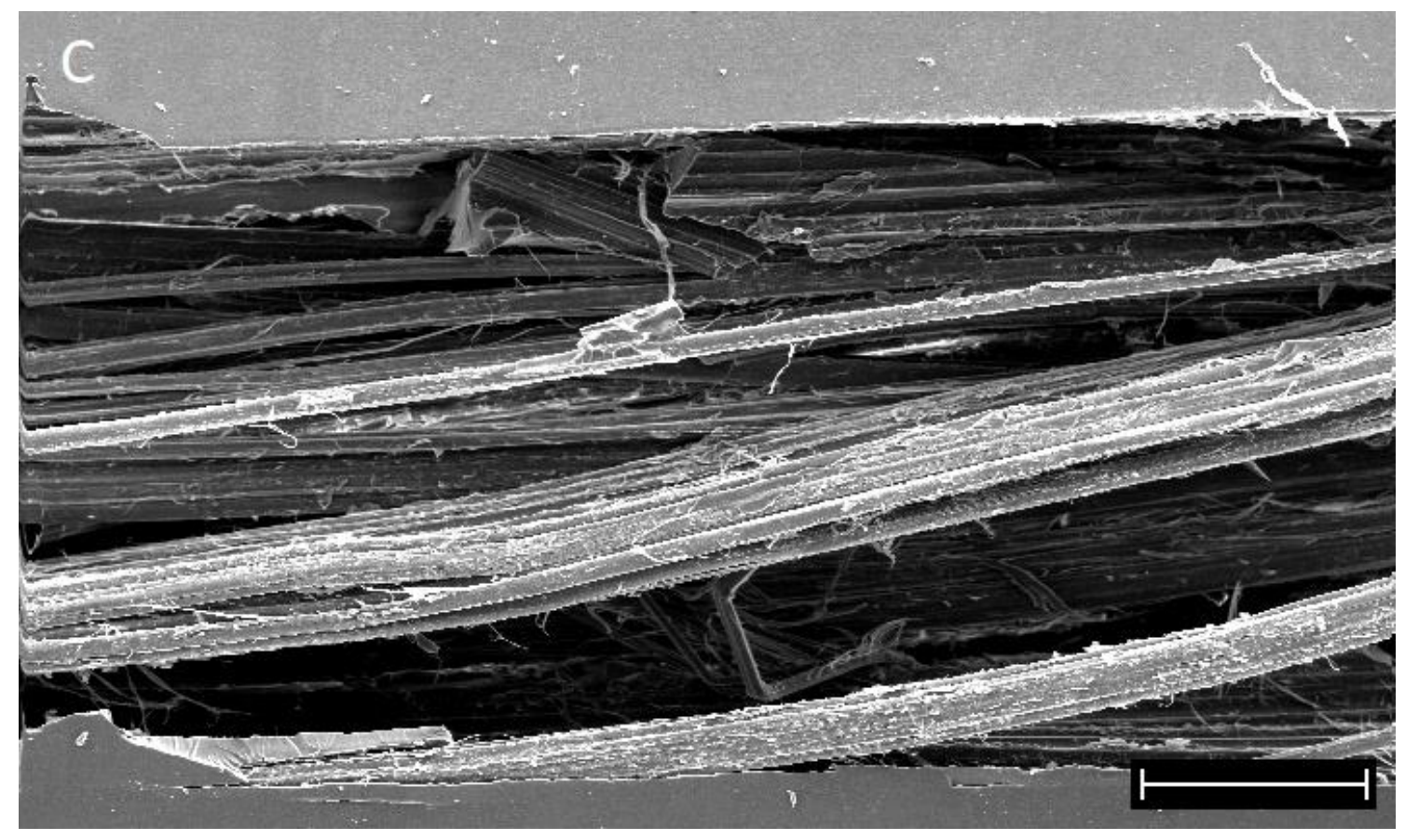

Figure 7. SEM analysis of fracture surfaces of three-point bending test composite samples with fibers treated with (A) water (96x), (B) EDTA (98x) and (C) PAn (101x). The scale bar represents $200 \mu \mathrm{m}$ 
Table 1. References and specifications concerning origin and extraction method

\begin{tabular}{|c|c|c|c|}
\hline References & Abbrev. & Origin & Extraction method \\
\hline Green fibers & GR & $\begin{array}{l}\text { Green flax from the Amina cultivar, } \\
\text { harvested by Verhalle in } 2015 \text { in } \\
\text { Belgium (VHGR15B) }\end{array}$ & Manual extraction \\
\hline $\begin{array}{l}\text { Fibers extracted after } \\
\text { water treatment }\end{array}$ & Water & $\begin{array}{l}\text { Green flax (VHGR15B) submitted to } \\
\text { water treatment with tap water at } \\
40^{\circ} \mathrm{C} \text { during } 24 \text { hours }\end{array}$ & Manual extraction \\
\hline $\begin{array}{l}\text { Fibers extracted after } \\
\text { EDTA treatment }\end{array}$ & EDTA & $\begin{array}{l}\text { Green flax (VHGR15B) submitted to } \\
\text { EDTA treatment with } 25 \text { mM EDTA } \\
\text { (pH 6.5) at } 40^{\circ} \mathrm{C} \text { during } 24 \text { hours }\end{array}$ & Manual extraction \\
\hline $\begin{array}{l}\text { Dew retted fibers, } \\
\text { manually extracted }\end{array}$ & $\mathrm{DRm}$ & $\begin{array}{l}\text { Dew retted flax from the Amina } \\
\text { cultivar, harvested by Verhalle in } \\
2015 \text { in Belgium (VHDR15B) }\end{array}$ & Manual extraction \\
\hline $\begin{array}{l}\text { Dew retted fibers, } \\
\text { mechanically extracted by } \\
\text { scutching }\end{array}$ & DRs & $\begin{array}{l}\text { Dew retted flax (unknown cultivar) } \\
\text { harvested by Vanacker Rumbeke in } \\
2017 \text { in France }\end{array}$ & $\begin{array}{l}\text { Mechanical extraction } \\
\text { with breaking and } \\
\text { scutching }\end{array}$ \\
\hline FlaxTape & FT & Lineo, unknown cultivar & $\begin{array}{l}\text { Mechanical extraction } \\
\text { with breaking, scutching } \\
\text { and hackling }\end{array}$ \\
\hline
\end{tabular}


Table 2. Overview of different treatments of flax (fibers were all manually extracted)

\begin{tabular}{|c|c|c|c|}
\hline Treatments & Abbrev. & Enzyme activity & Conditions \\
\hline Water treatment & Water & / & $40^{\circ} \mathrm{C}, 24 \mathrm{~h}$ \\
\hline EDTA treatment & EDTA & / & $25 \mathrm{mM}$ EDTA, $\mathrm{pH} 6.5,40^{\circ} \mathrm{C}, 24 \mathrm{~h}$ \\
\hline \multicolumn{4}{|l|}{ Pectinases } \\
\hline Scourzyme L & Sc & Pectate lyase & $25 \mathrm{mM}$ EDTA, $\mathrm{pH} 6.5,40^{\circ} \mathrm{C}, 24 \mathrm{~h}$ \\
\hline NS59049 & NS & Pectin lyase & $25 \mathrm{mM}$ EDTA, $\mathrm{pH} 6.5,40^{\circ} \mathrm{C}, 24 \mathrm{~h}$ \\
\hline Rohapect MPE & MPE & Pectin methylesterase & $25 \mathrm{mM}$ EDTA, $\mathrm{pH} 6.5,40^{\circ} \mathrm{C}, 24 \mathrm{~h}$ \\
\hline $\begin{array}{l}\text { Polygalacturonase from } \\
\text { A. niger }\end{array}$ & PAn & Polygalacturonase & $25 \mathrm{mM}$ EDTA, pH $6.5,40^{\circ} \mathrm{C}, 24 \mathrm{~h}$ \\
\hline \multicolumn{4}{|l|}{ Hemicellulases } \\
\hline Pulpzyme & $\mathrm{Pz}$ & Xylanase & $25 \mathrm{mM}$ EDTA, pH $6.5,40^{\circ} \mathrm{C}, 24 \mathrm{~h}$ \\
\hline $\begin{array}{l}\text { Xylanase from } T \text {. } \\
\text { lanuginosus }\end{array}$ & $\mathrm{XTI}$ & Endoxylanase & $25 \mathrm{mM}$ EDTA, pH $6.5,40^{\circ} \mathrm{C}, 24 \mathrm{~h}$ \\
\hline
\end{tabular}


Table 3. Results of analysis of fiber fineness with average, median and maximum value as well as percentages of fiber widths higher than $300 \mu \mathrm{m}$ and smaller than $100 \mu \mathrm{m}$

\begin{tabular}{lccccc}
\hline \multicolumn{1}{c}{ Treatment } & $\begin{array}{c}\text { Average } \\
(\boldsymbol{\mu m})\end{array}$ & $\begin{array}{c}\text { Median } \\
(\boldsymbol{\mu m})\end{array}$ & $\begin{array}{c}\text { Maximum } \\
(\boldsymbol{\mu m})\end{array}$ & $\begin{array}{c}\% \\
\mathbf{3 0 0} \boldsymbol{\mu m}\end{array}$ & $\begin{array}{c}\text { \% } \\
\mathbf{1 0 0} \boldsymbol{\mu m}\end{array}$ \\
\hline References & & & & & \\
GR & 218 & 169 & 974 & 26.4 & 27.6 \\
WATER & 114 & 106 & 614 & 2.2 & 49.7 \\
EDTA & 113 & 85 & 614 & 1.9 & 50.2 \\
DRm & 140 & 106 & 762 & 8.8 & 46.2 \\
DRs & 116 & 106 & 508 & 1.8 & 47.3 \\
FT & 83 & 64 & 551 & 0.2 & 68.9 \\
\hline Pectinases & 167 & 148 & 953 & 9.7 & 26.2 \\
Sc & 145 & 127 & 741 & 6.2 & 33.6 \\
Ns & 152 & 148 & 635 & 6.5 & 30.1 \\
MPE & 152 & 127 & 741 & 8.0 & 33.1 \\
PAn & 157 & 148 & 699 & 8.6 & 32.9 \\
\hline Hemicellulases & 173 & 148 & 805 & 11.5 & 27.6 \\
Pz & & & &
\end{tabular}


Table 4. Moisture absorption results of composites impregnated with enzymatically treated fibers compared to green flax fiber composites: equilibrium moisture content (\%) and diffusion coefficient $\left(\mathrm{mm}^{2} / \mathrm{s}\right)$

\begin{tabular}{lcc}
\hline Treatment & $\begin{array}{c}\text { Equilibrium moisture content } \\
\mathbf{( \% )}\end{array}$ & $\begin{array}{c}\text { Diffusion coefficient } \\
\left(\mathbf{1 0} \mathbf{~}^{-5} \mathbf{~ m}^{\mathbf{2}} \mathbf{/ s} \mathbf{)}\right.\end{array}$ \\
\hline GR & $6.05 \pm 0.75$ & $9.04 \pm 1.05$ \\
Sc & $4.55 \pm 0.22$ & $2.53 \pm 0.19$ \\
NS & $5.40 \pm 1.35$ & $1.68 \pm 0.60$ \\
MPE & $4.49 \pm 0.16$ & $1.92 \pm 0.27$ \\
PAn & $4.01 \pm 0.15$ & $1.00 \pm 0.19$ \\
Pz & $4.65 \pm 0.17$ & $5.39 \pm 0.73$ \\
XTI & $4.30 \pm 0.51$ & $3.39 \pm 0.47$ \\
\hline
\end{tabular}

